Training, Language and Culture, 4(1), 44-54. Doi: 10.22363/2521-442X-2020-4-1-44-54

У ДК 811.111

https://doi.org/10.25076/vpl.42.03

А.В. Радюк

К.Г. Девятникова

Российский университет дружбы народов

\title{
КРИТИЧЕСКИЙ ДИСКУРС-АНАЛИЗ \\ СТИГМАТИЗИРОВАННЫХ ПРЕСУППОЗИЦИЙ В СРЕДСТВАХ МАССОВОЙ ИНФОРМАЦИИ
}

\begin{abstract}
Целью данной статьи является выявление стратегий манипуляций на основе стигматизированных пресуппозищий, которые оказывают наибольшее влияние на аудиторию в медийном дискурсе. Автор рассматривает стигматизированные пресуппозищи как средство противопоставления категорий “свой" - "чужой”, где "чужсие" зачастую описываются при помощи стигм, обращающихся к негативным пресуппозищиям в сознании субъекта манипулящии. Манипулятивный потенциил стигматизированных пресуппозиций заключается в их возможности навязывать ложные представления об объекте, или путем добавления к этому объекту нерелевантных атрибутов, или путем импликации ложной пресуппозиции. Исследование основано на методах описательного, качественного $u$ количественного анализа манифестаций манипулящии в медиадискурсе. Примеры манифестачий манипулятивного дискурса были отобраны из популярных источников СМИ: Тhe Guardian, The Times, CNBC, BBC, CNN, YouTube, Medium, blogspot.com, reddit.com. В ходе исследования были выявлены следуюшие стратегии манипулирования, основанные на использовании стигматизированных пресуппозиций: апеллящия $\kappa$ личности, сочиальная категоризачия, гендерные и расовые стигмы, какография и самостигматизация. Манипулятивный потенциал стратегий был оценен при помощи фокус-группы. Механизм манипуляции был проанализирован в рамках каждой стратегии, выявив использование ошибочной атрибуции и
\end{abstract}


эмоционально насыщенной семантичности. Данная статья вносит вклад в развитие дискурсивного анализа лингвистических манипуляций и предлагает перспективу дальнейиих исследований в этой области.

Ключевые слова: манипулящия, медиадискурс, дискурс-анализ, стигматизация, пресуппозиция, гендерные и расовые стигмы, самостигматизация, какография

UDC 811.111

https://doi.org/10.25076/vpl.42.03

A.V. Radyuk

K.G. Devyatnikova

RUDN University

\section{CRITICAL DISCOURSE ANALYSIS OF STIGMATIZED PRESUPPOSITIONS IN MASS MEDIA}

The aim of this article is to identify manipulative strategies with stigmatized presuppositions which have the greatest impact on the audience in the media discourse. The author considers stigmatized presuppositions as a means of the opposition between the categories "the native" - "the outsider", where "the outsiders" often described with stigmas referring to negative presuppositions of the recipient. Manipulative potential of stigmatized presuppositions lies in their possibility to transmit false ideas about the object, whether by adding some irrelevant attributes to this object, or by implicating a fallacious presupposition. The research includes methods of descriptive, qualitative and quantitative analysis of manipulative manifestations in media discourse. The samples of manifestations of manipulative discourse were selected from the popular media sources: The Guardian, The Times, the CNBC, the BBC, The CNN, YouTube, Medium, blogspot.com, reddit.com. During the research the following strategies exercising stigmatized presuppositions were revealed, namely appeal to personality, social categorization, gender and race stigmas, cacography and self-stigmatization. The manipulative potential of the strategies was estimated by the focus group. The mechanism of manipulation was analyzed in the framework of each strategy, identifying the use of fallacious attribution and emotionally 
loaded semantization. This section is expected to contribute to the discourse analysis of linguistic manipulation and suggests prospect of further research in this field.

Key words: manipulation, media discourse, discourse analysis, stigmatization, presupposition, gender and race stigmas, selfstigmatization, cacography

\section{Introduction}

The theory of critical discourse analysis is considered as one of the fundamental theories by a series of studies of manipulative phenomenon, since it differentiates the linguistic aspect of communication. Discourse analysis theory helps to identify hidden intentions of the manipulator and the results of the whole manipulative process as a part of the system of social interactions. In this system the language is considered as one of the crucial factors of coercion and domination in communication.

Linguistic means facilitate the exercise of power and control over the audience due to both ambiguous and clear stated structural relationships. Many linguists studied manipulative discourse through the use of critical discourse analysis approach (S. Billig, A. Blommaert, P. Chilton, N. Fairclough, R. Koller, P. McLaren, L. Hamilton, T. van Dijk, R. Wodak, etc.). The most well-known scientist, which works are considered fundamental in this sphere is the Dutch linguist T. van Dijk. He deals with manipulation phenomenon using discursive, pragmatic and cognitive approaches. As far as manipulation is concerned, van Dijk underlined its hidden nature, abusive influence and negative intention on the part of manipulator (Dijk, 2006).

In the core of van Dijk approach lies the theory of the "triangle", which is based on the combination of three important components: the discourse itself, which is presented in the texts and conversation; the cognition, since the manipulation is connected with the process of information inferencing; and the society, due to the fact that certain social groups are included into conversation and subjected to the informational abuse from the manipulator. These three components are interrelated and comprise an integrated theory, which allows us to examine the manipulative phenomenon from the point of view of various factors.

Since the object of the study of critical discourse analysis is the 
relationships between language and society, it might be considered a proper approach to the analysis of manipulative media discourse in particular. Manipulative media discourse is characterized by the conflict of presuppositions, being expressed hiddenly or clearly. This conflict is of a great interest to the linguists which use critical discourse analysis in their studies. A presupposition should be considered as an assumption which is to be accepted a priori for the whole utterance to make the sense (Zharina, 2017). The presupposition refers to some knowledge relevant to the particular context and social group. This knowledge comprises initial and taken-for-granted, undisputed and undebatable presumptions related to all the spheres of the society and based on the mutually shared cultural background, ideology, beliefs, stereotypes, opinions, attitudes, models of behavior. The reference to cultural knowledge makes the transmitted information relevant and important for the recipient.

Being implicated in the message, presuppositions activate the information inference by the recipient, makes it more effective and efficient (Greco, 2003; Radyuk, Poliakova, 2018, Popova, 2018). Besides it may challenge the common knowledge, introducing some new presuppositions or modifying the existing ones. Therefore, presuppositions may be considered a means of manipulation, since it not only strengthens the reference to mutually shared knowledge, getting from the people's conscious the information about object, models of reaction, causes and probable consequences, but can also influence the information inference coercing the recipient to take the manipulator's point of view.

Manipulation with presuppositions is not limited to interpersonal communication, it has the ability to form and influence the audience, therefore should be studied as a global phenomenon. Manipulative presuppositions could affect all the spheres of social communication, including the communication between social groups and institutions: political leaders effectuate this type of manipulation influencing their voters, business corporations attack their clients, influencers attract the followers, etc. In this system mass media is the most comprehensive component, since it could act not only as a manipulator, but as a mediator of manipulation as well. So, the media discourse deserves particular attention in the investigation of manipulative phenomenon. Manipulative process in the media discourse is a complex system based 
on three major aspects: the presence of manipulator's aims and intentions, the ignorance of the recipient/audience of the underlying presuppositions, and the media source ( $\mathrm{TV}$, radio, newspapers, the Internet).

The initial manipulator's approach lies in the presence of positive representation of one side and negative representation of another side. In this article, we stick to the definitions suggested by Koroleva (Koroleva, 2017), describing these two sides as "the native" and "the outsider" respectively. Both sides are evaluated according to the "ideological square" model, where the positive characteristics of "the native" are put forward, negative traits are hidden, while in terms of "the outsider", it is vice versa: the negative features of are emphasized and the merits are diminished. "The outsider" is presented as a threat to "the native" itself and its most valuable resources: territory, property, nationality, religion, health, interests, etc. The distinction "the native" "the outsider" helps people to identify themselves with a social group possessing its own mutually shared background and cultural knowledge, represented in a system of acceptance and evaluation of attitudes and behavioral models. This system is hierarchical and facilitates the perception of the reality, on the one hand, and sets parameters for manipulation, on the other hand.

Critical discourse analysis studies different context of dynamic social and linguistic categories in order to explain the opposition "the native - the outsider". It is the categorization of the society in accordance with statuses, roles and ideologies which has led to the polarization "we" - "they". This polarization affected the thematic diversification of the information, use of peculiar linguistic means to modify the utterance in the way to be the most relevant to a particular social category. Taking into account that the target recipient belongs to a certain social category, the manipulator seeks to structure and deliver the information in the most efficient way to achieve his aims and intentions. The more accurate the target audience's properties are determined, the more manipulative the message might be. Referring to a commonly shared presupposition of a recipient from a particular social category (which is determined according to his distinct traits: if he a man or a woman, believer or atheist) allows the manipulator to predict possible evaluation and subsequent reaction on the manipulation. In his turn, the recipient estimates the message according 
to his internal presuppositions (acquired due to the personal background) and external presuppositions (reflecting the opinion of a respectful authority of the social group), and finding no contradictions, eager to think that he made the judgment by himself. In fact, the whole process was organized and monitored by the manipulator from the very beginning.

Mass media can manipulate various social categories in their own interests by selecting proper approach to manipulation. One of the approaches, where the opposition "the native" - "the outsider" is highly expressed is known as stigmatization. Stigmatization or labeling is the process of discrimination of a person or social group on a basis of features which distinguish him/them from others. A discriminated object is described with the use of a certain "stigma" - a succinct and concise attribute based on its culture, race, nationality, gender, age, sexual orientation, level of education, physical characteristics (Holley, 2016). G. Falk wrote about the high tendency of social groups to stigmatize each other due to the necessity to reach solidarity in a particular social group, and distinguish "the outsiders" from "the native" (Falk, 2001). Being a social object the person pursuits to associate himself with a social category and suppress other categories struggling for survival. Putting stigmas on the surrounding objects creates the hierarchy in comprehension and evaluation of attitudes and behavioral models (Link, Phelan, 2001).

The stigmatization of an object is a certain presupposition in its core, comprising the cultural knowledge about this object in a particular social group. The stigmatized presupposition is a means of opposition "the native" to "the outsider", which forms the utterance with special linguistic tools and makes sense only if both the speaker and the recipient imply the same presupposition. Manipulative potential of stigmatized presuppositions lies in their possibility to transmit false ideas about the object under discussion, whether by adding some irrelevant attributes to this object, or by implicating an underlying presupposition, different from the obvious one. In the first case, the stigmatized presuppositions are based on some well-known to the recipient and thus creditable and undebatable stigmas. The delivered information seems relevant, correspond to the personal experience the recipient, therefore he tends to inference it with least possible efforts, quickly establishing the connections between the new information and 
well-known presupposition about the stigma. In the case of implicating of an underlying presupposition, stigma covers the manipulative actions of the speaker, focusing the attention of the recipient on the comprehensible part of information. To make the process of manipulation successful to speaker has to deal with more sophisticated manipulative strategies to cover the presuppositional fallacy (Engel, 1994).

In this article we might define a manipulative strategy as a linguistic aspect of information delivery, appropriate to the context and statuses of the components of manipulation (i.e., initiator, recipient, media resource), containing imperceptible presupposed message influencing the recipient to act in accordance with the expectations of manipulator (Malyuga, \& Tomalin, 2017). It should be stressed that the manipulative message is imperceptible since it could not be detected by our perception, only by critical and logical reasoning. The preset goal is unachievable, if the recipient detects the manipulative intention of the speaker. If the manipulation is successful, the recipient is prevented from critical reasoning. He is forced to act in accordance with the presupposed will of manipulator, tends to choose the behavioral model, predicted by the manipulator. Efficient manipulative strategies impede the recipient to understand that the information does not corresponds to the reality, covering the intentions of the manipulator. The transmitted presuppositions are defective, so they can be incorrect to some extent, invalid, inaccurate or do not correspond the reality, therefore such presuppositions might be rejected when happening in usual conditions. Without the proper use of manipulative strategies, the speaker might not be able to influence the recipient, change his way of inference and modify his attitudes or behavior.

In our research we focused on the evaluation of 5 most popular manipulative strategies implying stigmatized presuppositions. These strategies were differentiated by discourse analysis of manipulative manifestations in media discourse where the total number of samples equals 800, and the number of samples featured 'stigmatized presuppositions' equals 320. These strategies are as follows: appeal to personality, social categorization, gender stigmas, cacography and selfstigmatization. They reflect the general idea of polarization of "the native" and "the outsider" and imply certain stigmatized presuppositions to transmit the idea of polarization, stratification and 
inequality, helping the manipulator to unify himself with the target audience in a particular group.

\section{Appeal to personality}

Appeal to personality focuses on criticizing of the person for his personal qualities or attributes, discrediting his social image by using shameful facts, improper comparisons, adding fallacious information or making illogical judgments. The manipulator might use the strategy of discreditation of the object of discussion appealing directly to his personal characteristics, both external (connected with his appearance and manners) and internal (personal qualities and skills). Such a strategy is quite widespread in political media discourse, where the opponents cross the line of moral standards, insulting and humiliating each other.

\section{Social categorization}

This strategy is based on the distinction between "the native" and "the outsider", where recipients of the conversation relate themselves to a certain social group or category. The incoming presuppositions are evaluated according to the system of acceptance and estimation of attitudes and opinions. If the manipulator relates himself to the category of "the native", he might facilitate the whole process of manipulation, since the recipient would like to listen to someone from their social category.

\section{Gender and race stigmas}

Gender media discourse might be characterized by a frequent use of stigmas. Presuppositions made on the base of stigmas influence the judgments made by the recipient in a direct way, almost suggesting him the easiest way of thinking and estimating the object of conversation, often in a quite negative way (Alkhammash, \& Al-Nofaie, 2020). Stigmatization of the object as male or female allows the recipient to estimate this object in accordance with the stereotypical criteria of the category under discussion. These gender criteria belong to highly relevant for the recipient social and cultural ideology.

\section{Cacography}

Another strategy of manipulation with stigmatized presuppositions is cacography, which presents a deliberately misspelled word or expression, where the literary norm is changed by a native speaker change is made by a native speaker providing the special effect on the recipient by activating some additional frames and modes of 
inferencing. The distorted words are unique and expressive, they are a good way to catch the recipient's attention. One of the advantages of the cacography is a succinct form of the expression, the presupposition might be implemented in one word.

\section{Self-stigmatization}

The strategy of self-stigmatization is implied when the manipulator tries to create a good image of himself, relating certain stigmas to the social image of his personality in order to modify or foster the very idea of his moral fiber, his belonging to this or that social category or devotion to certain ideals.

The main aim of the article is to identify manipulations with stigmatized presuppositions in the media discourse which have the greatest impact on the audience.

Thus, the objectives of the article are:

1) to reveal the strategies of implementation of stigmatized presuppositions in the media discourse;

2) to identify the strategies which have the greatest impact on the target audience:

3 ) to describe the mechanism of manipulation in the framework of each strategy.

\section{Methodology}

The methodology comprises methods of descriptive, qualitative and quantitative analysis of manipulative manifestations in media discourse. On the first stage, the passages with manifestations of manipulative discourse were selected from the popular media sources: The Guardian, The Times, the CNBC, the BBC, The CNN, YouTube, Medium, blogspot.com., reddit.com. Next, these passages were analyzed from the point of view of van Dijk's critical discourse analysis. The strategies of manipulation in the media discourse have been revealed. Several samples of different manipulation manifestations were collected to the following assessment by the focus group. The total number of manifestations selected by the author was 800 , the number subdued to the evaluation (stigmatized presuppositions category) equals $312(39 \%)$.

On the second stage, the selected passages with stigmatized presuppositions were evaluated by the focus group to identify the strategies which have the greatest impact on the target audience. The second stage was split in several steps due to a great number of 
manifestations. Focus group comprised 20 Russian respondents speaking English at $\mathrm{C} 1$ level, aged 21-27 were proposed to assess the influence of a manifestation according to the following scale (table 1).

Table 1. The rating scale of stigmatized presuppositions assessment

\begin{tabular}{|l|l|l|l|l|l|}
\hline Point & \multicolumn{1}{|c|}{-2} & \multicolumn{1}{c|}{-1} & \multicolumn{1}{c|}{0} & \multicolumn{1}{c|}{2} \\
\hline Meaning & $\begin{array}{l}\text { I strongly } \\
\text { disagree/ } \\
\text { that is a lie }\end{array}$ & $\begin{array}{l}\text { I think I } \\
\text { disagree }\end{array}$ & $\begin{array}{l}\text { no fixed } \\
\text { opinion }\end{array}$ & $\begin{array}{l}\text { I think } \\
\text { I } \\
\text { agree }\end{array}$ & $\begin{array}{l}\text { I strongly } \\
\text { agree/ that } \\
\text { is the truth }\end{array}$ \\
\hline
\end{tabular}

\section{Results and discussion}

The samples of stigmatized presupposition were classified in five groups according to the strategy of manipulation, namely appeal to personality, social categorization, gender and race stigmas, cacography and self-stigmatization. Critical discourse analysis allowed us to estimate the frequency of above-mentioned strategies. Total number of manifestations with stigmatized presuppositions is 312 . The obtained results are presented in the table 2.

Table 2. The distribution of strategies implying stigmatized presuppositions in media discourse

\begin{tabular}{|c|c|}
\hline Strategy & Frequency, \% \\
\hline Appeal to personality & 30,77 \\
\hline Social categorization & 26,28 \\
\hline Gender/race stigmas & 28,53 \\
\hline Cacography & 4,17 \\
\hline Self-stigmatization & 10,26 \\
\hline
\end{tabular}

As it could be seen the most widespread strategy is appeal to personality $(30,77 \%)$. Quite frequent are also the strategies of gender and race stigmatization and social categorization (28,53 and 26,28\% respectively). Less used are the strategies of self-stigmatization $(10,27 \%)$ and cacography $(4,17 \%)$.

On the next stage, the samples were subdued to assessment by the focus group. The evaluation was conducted in several steps, the members of the focus group were the same. The participants of evaluation were proposed to subjectively assess the influence of 
manipulation according to the rating scale (see table 1). The assessment scale comprised five points of rating, from -2 to 2 , expressing the agree of the recipient with the message. The results of the assessment are specified in the table 3 .

Table 3. The average coefficient of influence o manipulative strategies on the focus group

\begin{tabular}{|c|c|}
\hline Strategy & Average coefficient of influence \\
\hline Appeal to personality & 1,22 \\
\hline Social categorization & 0,93 \\
\hline Gender/race stigmas & 0,87 \\
\hline Cacography & 0,77 \\
\hline Self-stigmatization & 0,13 \\
\hline
\end{tabular}

In general, it could be explicitly observed that the strategy of appeal to personality has exercised the strongest influence on the focus group. It is not only the most widespread strategy of stigmatized presuppositions implemented into the context by a manipulator, but also the most effective one (Radyuk, 2016). Next three strategies, namely social categorization, gender and race stigmas and cacography showed medium-strength manipulative potential due to the people's awareness of inappropriateness of discriminative judgments, while the linguistic aspect of these strategies from some point of view was considered derogatory that led to a reduced criterion of objectivity. Self-stigmatization has happened to show the least manipulative potential, since it is based on the positive self-presentation of the speaker which has not such a great influence as a negative one.

The mechanism of manipulation, which reflects the potential of the strategy's influence and bases on the characteristic features of the particular strategy, was analyzed in the framework of each strategy. The results of discourse analysis of the strategies implying stigmatized presuppositions are presented below.

\section{Appeal to personality}

The first strategy of application of stigmatized presuppositions is the appeal to the personality strategy. In the following example Biden discredits Trump, accusing him of being the racist:

(1) CHRIS WALLACE: What is radical about racial sensitivity training? (rev.com) 
TRUMP: If you were a certain person, you had no status in life. It was sort of a reversal. And if you look at the people, we were paying people hundreds of thousands of dollars to teach very bad ideas and frankly, very sick ideas. And really, they were teaching people to hate our country And I'm not going to do that. I'm not going to allow that to happen. We have to go back to the core values of this country. They were teaching people that our country is a horrible place. It's a racist place. And they were teaching people to hate our country. And I'm not going to allow that to happen. (rev.com)

BIDEN: Nobody's doing that. He's the racist. (rev.com)

Appealing to a certain personality the manipulative strategy evokes evoke some mutually shared cultural norms and standards, presented in presuppositions. These presuppositions become accepted by the recipient since he belongs to a particular category or group of the society, which tries to stick to a number of moral standards, models of behavior and inferencing of information. Appealing to the existing preestablished patterns, which are commonly shared and thus known pretty well, raise the influencing power of the message. The inference is more stable and predictable in such conditions, since the connections of the delivered information with the relevant presuppositions in the cognitive environment of the recipient is faster. In the example (1) one of the most obvious presupposition transferred by Biden is that Trump is the racist. This is an example of stigmatized presupposition appealing to a certain personality. Calling Trump 'the racist' Biden force the recipient cognition to associate the ex-president with a negative image of a racist, which is laying upon the previously experienced inferencing of this presupposition. There is also an underlying presupposition, namely "Nobody's doing that". Saying this Biden estimated the model of Trump's behavior as socially unacceptable, discredits him, comparing his actions with generally accepted in the society, which pretends to be negative and inappropriate. The word racist which is loaded emotionally as well as a negative pronoun nobody, strengthen the manipulative potential of the strategy.

\section{Social categorization}

Stratification and categorization of the society are quite often reflected in commonly used stereotypes and presuppositions. The following examples transmit the idea of a glass ceiling, which is impassable to some social classes in education, career choice and life. 
(2) "Growing up in lower social classes is as significant an obstacle to becoming a manager" (Academy of Management).

(3) "Everyone here ought to watch this. Human beings are no longer mysterious souls. They are hackable machines. At some point the lower classes are described as rats" (Comment to How to Survive the XXI century? WEF, YouTube)

(4) "Individual teachers are holding lower academic expectations for children of immigrants and focusing on what Adair calls "narrow learning experiences." (New America)

In the examples (2) the people belongness to the category of lower social classes obtain stigmatized presuppositions as an obstacle to get a better career position, though there is no direct logical correspondence between two presuppositions. Example (3) compares lower class representatives with rats, transferring the idea of humiliation and raising aggressive reaction of the recipient. Though, it should be noted that the manipulator associates himself with the category lower classes, including in the strategy of social categorization the opposition "the native" - "the outsider", which reflects the underlying presupposition of the message. This presupposition facilitates the polarization between "us - lower classes, underestimated and suffering people" and "them upper classes, wealthy people, who get what they want just from the fact of belongness to that group". The polarization facilitates the influential potential of the strategy, since it increases the creditability of the manipulator (Leudar, Marsland \& Nekvapil, 2004).

Example (4) contains several presuppositions, namely "lower academic expectations" and "narrow learning experiences" related to the social category "the children of immigrants". In this case the unification of the manipulator with the audience might not be traced, though he separates himself from the speaker, indicating his role as an intermediary of communication (reference to the original actor individual teachers, Adair calls). That means that he does not support the presuppositions. Although, the potential of this message influence on the target audience is still high because of the incomplete comparison lower academic expectations. This comparison is incomplete, because there is no social group to compare the expectations with. This is a type of fallacious argument, since it could not be verified and refuted. The effect of denigration is also achieved by proper semantics: adjectives lower, narrow, word immigrants with a 
huge emotional load, evoking negative presuppositions, connected with it.

\section{Gender and race stigmas}

Gender and race stigmas are quite a popular strategy of manipulation in media discourse since they also appeal to certain characteristics of an individual and polarized him and the group with the opposite features (woman/ man, black/white, etc.). Each gender and race are associated with a number of presuppositions, usually unpleasant and uncomfortable to the object of communication. These presuppositions accentuate some attributes of a gender/race and form negative evaluation of the category. According to the commonly shred presuppositions women should comply with traditional image with feminine characteristics (tenderness, femininity, softness, meekness; housekeeping, raising children, showing respect and support to the husband). They are discredited for unfulfillment of their 'duties' and pretend to be a man and effectuate attributed to him social roles and functions. Men is derogated vice versa: for being too feminine, doing 'women's job' and enjoying women's activities. In examples (5) and (6) such presuppositions might be detected. The manipulator uses the parallel construction and makes the direct connection between emotionally loaded adjectives, which implies the presupposition of a girl, namely strong, powerful - (not) appropriate, attractive. Besides, men are polarized with women by having the opportunity for being ambitious, the presupposition does not endow women with such a quality. Both examples contain the presuppositions derogating women in comparison with men:

(5) "being strong and powerful and outspoken just wasn't appropriate or attractive for a girl" (The CNBC)

(6) "The thing that gets me the most is when they tag you with "ambitious," as if it's a bad thing. You would never criticize a man for being ambitious, but with a woman it's a different story" (Times)

Example (7) reveals the opposition "the native" - "the outsider", with the speaker directly involved in this opposition. Stigmas of this presupposition refer both to gender and race of the participants: Asian girl-Caucasian men, provoking a chain of presuppositions, based on the previous experience with these categories. The manipulative potential of the message is enhanced through the use of semantically loaded adjective mixed: 
(7) "They all started laughing hysterically, giving each other high fives. Curious, I asked, "What's so funny?" In between laughs, one of them uttered, "Oh, we can't share this in mixed company." Three Caucasian men. One Asian girl. I was dampening their fun. What could they possibly be looking at during work hours that they can't share in mixed company?" (Medium)

Since the theme of gender and race inequality and discrimination is relevant for ages, mass media are highly interested in raising tensions in the confrontation of the oppositional categories. They are constantly shared information with the stigmatization of this or that gender and race, social minorities. A heterogenous semantics in this field comprises stigmas (white man, black woman, man's job, girls'/boys' sports, LGBTQ+ community, etc), slogans (Black lives matter, Love is love, Women empowerment, Me too, gender fluid), denigrated comparisons and insultations. The manipulative strategy is often applied without additional coverage, hitting the emotions of self-esteem and pride.

In example (8) quite uncovered opposition of white - African American/black (men) could be seen. The semantics

of description of both categories exercise huge manipulative potential, apologizing white men calling them "happy revelers", "out of control fans", while the second category of African American men are depicted as "dangerous thugs". In the example (9) emotionally loaded stigma "Ebola" is used to the people of Senegal, discrediting and separating them from the surrounding.

(8) "Young white men smashing windows, overturning cars, and battling police after a big athletic event are "revelers," "out of control fans." But a group of mostly African American youth who do similar things out of sorrow and rage that a young black man has died in police custody are dangerous "thugs." The difference in the two descriptions is telling. Happy "revelers" whose youthful celebration "got a little out of hand" can be corrected and forgiven. "Dangerous thugs" present a much more ominous threat." (Time)

(9) "the bullying began soon after his two sons arrived at their New York City school from Senegal almost one month ago. They were called "Ebola" by other students, taunted about possibly being contagious and excluded from playing ball" (The Independent)

Gender and race stigmas are aimed at distinct polarization of "the 
native" and "the outsider", often with the use of semantics to evoke certain stereotypical presuppositions in the mind of the recipient during the information processing.

\section{Cacography}

Distortion of the word or expression for them to be related to a certain presupposition increase the manipulative potential of the message. Successfully misspelled, it becomes a new expression which represent a stimulus for information inference by the recipient. If the form of a cacography is clear and succinct, easy to remember and to pronounce, it could become a popular semantic means in the similar context. In addition, cacography may change the initial meaning of the word, adding some new properties and attributing extra features, beneficial for the manipulator. Examples (10-12) refer to is a quite widespread cacography Obamacare which describes Obama's health care policy. Through the several years of use in mass media, it has acquired negative connotation, being judged as inefficient. Example (13) shows the evolution of this cacography in relation with Trump's policy in this sphere - Trumpcare, which also obtained the negative image:

(10) "What I proposed is that we expand Obamacare and we increase it. We do not wipe any" (rev.com)

(11) "Former President Donald Trump refused to reopen Obamacare enrollment last spring and the coronavirus pandemic swept the nation" (The CNN)

(12) "Finally, we've got the Obamium" (reddit.com)

(13) "Man buys Trumpcare junk insurance. Now owes \$33,601 in medical bills" (Microsoft News)

The next example (14) shows a cacography with a humorous effect. The verb trump got the additional meaning of modifying the pictures of cats by adding to them ex-president's haircut. The noun trumpster was created to describe lovely and cute cats presented on those pictures. Finally, the name of the country America was misspelled as Ameowica to increase the hamorous effect and manipulative potential of the message. It should be said, that despite looking as a simple joke, this strategy might also be considered of manipulative character, since it humiliates Trump's social image and establish the presupposition not to take him seriously:

(14) "Trumping - making cats look like Donald Trump since 
2015. Look at this Tired Trumpster! What Ameowica needs!"
(imgur.com)

Examples (15-17) present an interesting case of cacography of a word woman. Some feminists try to use its modified singular form womyn (and in plural - womon), in order not to use suffices -man and men. Acting this way, they seek to separate from the male gender and avoid any associations with it. This strategy also acts as an opposition "the native" - "the outsider" though in another way. People who consider themselves as a part of the separating feminists use this form to underline and feel their group identity. In this case, the word womyn gets the positive presupposition of an independent woman. Those, who do not support the ideas of the first group, refer to the word womyn with a negative presupposition of an inadequate feminist. Although, in general, negative presuppositions have greater influence on the target audience, this case is considered debatable and needs further investigations:

(15) "New rule (rule 6): to avoid objectification, womyn should never be the grammatical object of a sentence" (reddit.com)

(16) "Masculinity exists basically to rape and subjugate womyn and make their lives miserable" (Tweeter)

(17) "Men have never achieved anything. Contrary to popular belief, womyn spearheaded the advancements of modern civilization" (YouTube)

\section{Self-stigmatization}

Self-stigmatization is the manipulative strategy which is based on positive presuppositions. Having a positive presupposition in its core, the message might cause unpredictable effect on the recipient. The manipulator may use an excessive flattery, aiming at creation of a good image of himself, which in the contrary, can evoke unnecessary emotions of the recipient and worsen his attitude to the manipulator (that happened when the focus group of this research was evaluating the influencing power of the strategy, expressing disbelief and unsureness to the manipulator). In following examples (18-20) a tendency of Russian people to adreess to our country as Mother Russia in English language media space, reach the aim of intimidation of the people of other nationalities. The emotion of fear provoked by this stigma is explained by the fact that, Mother Russia was originally the motto of soldiers going into battle 'For Mother Russia!': 
(18) 'In mother Russia you don't drive on road road drive on you" (reddit.com)

(19) "You see comrade: in Mother Russia, you don't tell the news, the news tells you" (blogspot.com)

(20) "Doesn't matter if it's 1941 or 2021, you don't mess with

Mother Russia!" (imgur.com)

Stigmatized presuppositions often aimed at attributing some irrelevant features to the object under discussion. Highlighting the negative features of the object under discussion, the manipulator increases the manipulative potential of the message. This effect is achieved due to the implication of the opposition "the native" - "the outsider". The manipulative potential of the stigmatized presuppositions depends to a higher extent on the context, but also on the appropriateness of the selected strategy. Since these presuppositions are based on stigmas, the semantics of the utterance should be done accurately and correctly.

\section{Conclusions}

In this article the author attempted to conduct discourse analysis of the stigmatized presuppositions in mass media discourse. Several strategies exercising stigmatized presuppositions were revealed, namely appeal to personality, social categorization, gender and race stigmas, cacography and self-stigmatization. These strategies are based on fallacious presuppositions, implicated by a manipulator to contextual stigmas. Stigmatization pursues the idea of the opposition between the categories "the native" - "the outsider", where "the outsiders" often described with stigmas referring to negative presuppositions of the recipient connected with the commonly shared knowledge or his personal unsuccessful experience.

The manipulative potential of the strategies was estimated by the focus group. The results have shown that the appeal to personality strategy has the greatest manipulative potential compared to medium influence of social categorization, gender and race stigmas and cacography, and weak role of self-stigmatization in the manipulative process.

The mechanism of manipulation was analyzed in the framework of each strategy. The general tendency of stigmatized presupposition is to discredit "the outsider" by manipulative use of the semantics, which helps to attribute to him some fallacious properties. Some existing 
presuppositions are modified by the manipulator, some new ones are added to the recipient's models of inferencing. Their influencing power is increased by the use of emotionally loaded lexis and semantics means.

This research contributes to the development of discourse analysis in the sphere of linguistic manipulation. For the further investigation of the issue the author suggests the case of cacography, where the question of the manipulative potential of positive presupposition from "the native" side and negative presupposition from "the outsiders" is to be studied.

Литература
1. Жарина О.А. Сущность терминов "пресуппозиция" и "презумпция" в современной когнитивной лингвистике // Балтийский гуманитарный журнал. 2017. №6 4 (21). С. 70-72.

2. Королёва Т.А. Лингвистические средства реализации социальной оппозиции «Свой - чужой» в политическом дискурсе // Филологические науки. Вопросы теории и практики. 2017. №5-2 (71). С. 85-88.

3. Радюк А.В., Полякова Н.В. Пресуппозиции в коммуникативных стратегиях рекламных мини-текстов // Вестник Красноярск. гос. пед. ун-та им. В.П. Астафьева. - 2017. - № 4 (42). - С. 160167. DOI: $10.25146 / 1995-0861-2017-42-4-31$

4. Alkhammash R., Al-Nofaie H. Do Saudi academic women use more feminised speech to describe their professional titles? An evidence from corpus // Training, Language and Culture. 2020. № 4(3). Pp. 920. Doi: $10.22363 / 2521-442 X-2020-4-3-9-20$

5. Engel S.M. With Good Reason: An Introduction to Informal Fallacies. St. Martin's, 1994. Pp. 198 - 206.

6. Falk G. STIGMA: How We Treat Outsiders. Prometheus Books, 2001.

7. Greco S. When presupposing becomes dangerous: How the procedure of presuppositional accommodation can be exploited in manipulative discourses // SCOMS (Studies in Communication Sciences). 2003. № 3(2). Pp. 217-234. 
8. Holley L. Heterosexism, racism, and mental illness discrimination: Experiences of people with mental health conditions and their families // Journal of Gay \& Lesbian Social Services. 2016. №28(2). Pp. 93-116. DOI: 10.1080/10538720.2016.1155520

9. Leudar I., Marsland V., Nekvapil J. On membership categorization: 'Us,' 'them' and 'doing violence' in political discourse // Discourse and Society. 2004. №15 (2-3). - Pp. 243 - 266.

10. Link B., Phelan Jo C. Conceptualizing Stigma // Annual Review of Sociology. 2001. № 27. Pp. $363 \quad$ - 385, doi:10.1146/annurev.soc.27.1.363

11. Malyuga, Tomalin B. Communicative strategies and tactics of speech manipulation in intercultural business discourse // Training, Language and Culture. 2017. № 1(1). Pp. 28-45. doi: 10.29366/2017tlc.1.1.2

12. Popova K. V. Persuasion strategy in online social advertising. // Training, Language and Culture. 2018. № 2(2). Pp.55-65. Doi: 10.29366/2018tlc.2.2.4

13. Radyuk A.V. Criteria of English Business Discourse Effectiveness in View of Dynamic and Systemic Approach // Vestnik Volgogradskogo Gosudarstvennogo Universiteta. Seriya 2 Yazykoznanie. 2016. №15 (3). Pp. 196-205. DOI: 10.15688/jvolsu2.2016.3.22

14. Van Dijk T.A. Multidisciplinary CD A: A Plea for Diversity // Methods of Critical Discourse Analysis / R. Wodak, M. Meyer. London: Sage, 2001. Pp. 95- 120.

15. Van Dijk T.A. Discourse and Manipulation // Discourse and Society. 2006. №17 (2). Pp. 359 - 383.

References

Alkhammash, R., \& Al-Nofaie, H. (2020). Do Saudi academic women use more feminised speech to describe their professional titles? An evidence from corpus. Training, Language and Culture, 4(3), 920. Doi: $10.22363 / 2521-442 X-2020-4-3-9-20$

Engel, S.M. (1994) With Good Reason: An Introduction to Informal 
Fallacies, (pp. 198 - 206). St. Martin's.

Falk, G. (2001). STIGMA: How We Treat Outsiders. Prometheus Books.

Greco, S. (2003). When presupposing becomes dangerous: How the procedure of presuppositional accommodation can be exploited in manipulative discourses. In SCOMS (Studies in Communication Sciences), 3(2), 217-234.

Holley, L., Mendoza, N., Del-Colle, M., \& Lynette-Bernard, M. (2016). Heterosexism, racism, and mental illness discrimination: Experiences of people with mental health conditions and their families // Journal of Gay \& Lesbian Social Services, 28(2), 93116. DOI: $10.1080 / 10538720.2016 .1155520$

Korolyova, T.A. (2017). Lingvisticheskie sredstva realizacii social'noj oppozicii «Svoj - chuzhoj» v politicheskom diskurse [Linguistic Means of Realizing the Social Opposition "Friend or Foe" in Political Discourse]. Filologicheskie nauki. Voprosy teorii $i$ praktiki, 5-2 (71), 85-88.

Leudar, I., Marsland, V., Nekvapil, J. (2004). On membership categorization: 'Us,' 'them' and 'doing violence' in political discourse. Discourse and Society, 15 (2-3), 243 - 266.

Link, B., Phelan, Jo C. (2001). Conceptualizing Stigma. Annual Review of Sociology, 27, 363-385, doi:10.1146/annurev.soc.27.1.363

Malyuga, E. N., \& Tomalin, B. (2017). Communicative strategies and tactics of speech manipulation in intercultural business discourse. Training, Language and Culture, 1(1), 28-45. doi: 10.29366/2017tlc.1.1.2

Popova, K. V. (2018). Persuasion strategy in online social advertising. Training, Language and Culture, 2(2), 55-65. Doi: 10.29366/2018tlc.2.2.4

Radyuk, A.V. (2016). Criteria of English Business Discourse Effectiveness in View of Dynamic and Systemic Approach. Vestnik Volgogradskogo Gosudarstvennogo Universiteta. Seriya 2 Yazykoznanie, 15 (3), 196-205. DOI: 10.15688/jvolsu2.2016.3.22

Radyuk, A.V., \& Poliakova, N.V. (2017). Presuppozicii V kommunikativnyh strategijah reklamnyh mini-tekstov [Presuppositions in the communication strategies of advertising mini-texts]. V.P. Astafyev Krasnoyarsk state pedagogical 
university Bulletin, 4 (42), 160-167. DOI: 10.25146/1995-08612017-42-4-31

Van Dijk, T.A. (2001) Multidisciplinary CD A: A Plea for Diversity. In R. Wodak, M. Meyer (Eds.) Methods of Critical Discourse Analysis, (pp. 95-120). London: Sage.

Van Dijk, T.A. (2006). Discourse and Manipulation. Discourse and Society, 17 (2), 359 - 383.

Zharina, O.A. (2017). Sushchnost' terminov "presuppoziciya" i "prezumpciya" v sovremennoj kognitivnoj lingvistike [The essence of the terms "presupposition" and "presumption" in modern cognitive linguistics]. Baltijskij gumanitarnyj zhurnal, 6 (4 (21)), 70-72.

У ДК 32.109.51, 808.51

https://doi.org/10.25076/vpl.42.04

Т.Ф. Усманов

М.С. Бройтман

Российский университет дружбы народов

\section{РЕПРЕЗЕНТАЦИЯ ОБРАЗОВ «ВРАГ»/ «ДРУГ» В СМИ ВЕНЕСУЭЛЫ}

Статья посвящена анализу и специфике венесуэльских СМИ в репрезентачии образа «врага» $u$ «друга» Венесуэль $и$ ее политических лидеров. Целью статьи является реконструкиия и интерпретация образов «врага» $и$ «друга» в наџиональной прессе Венесуэль, изучение инструментов, как журналистских, так и собственно языковых, используемых при создании новостных материалов, а также того, в какой степени эти инструменты и методы влияют на создание или изменение общественного мнения в парадигме «друг-враг». Актуальность данного исследования обусловлена острой политической ситуацией в Венесуэле, а именно противостоянием оппозичионной Национальной ассамблеи и правительства Венесуэль, которое проходит в том числе в медиапространстве. Новизна заключается в том, что до настоящего момента венесуэльские СМИ не были рассмотрены в качестве инструмента создания общественного мнения и образа «врага» и «друга» страны. Материалом исследования послужсили 